\title{
THE NATURAL ENVIRONMENT IS MORE THAN JUST DÉCOR Ecocritical Points of Departure in Contemporary Theatre Studies, the First Step in Quest of Slovak Eco-dramaturgy
}

\author{
MILO JURÁNI
}

Theatre Faculty of the Academy of Performing Arts, Bratislava

\begin{abstract}
The paper focuses on the mapping out of the current ecocritical discourse in drama and theatre. The theoretical approach examines models, productions, and various forms of performance with regard to the reflection on the impact of human activity on the environment. Current approaches make it possible, inter alia, to give prominence to works dealing with the relationship between man and his natural environment which, until recently, have been overlooked. There are various methods to analyse a work through ecological narrative, yet, there are simple tools that facilitate this work. Among these tools is the questionnaire of the American theatrologist Theresa J. May entitled Some Green Questions to Ask a Play. This theoretical tool was employed in the analysis of the play Margaret zo zámku [Margaret from the Castle] by the Slovak playwright Štefan Králik. One of his last plays, which has not resonated particularly well with the critique, seems to be a key contribution to the Slovak so-called eco-dramaturgy. At the same time, the study raises the question of the perception of ecologically committed plays originating in the Eastern Bloc countries and burdened with the ideology of their time. This is a specific situation that the ecocritically oriented researchers in Western countries have not been confronted with, and at the same time, it poses a challenge to the whole Eastern ecocriticism.
\end{abstract}

Key words: the environment, ecology, nature, ecocriticism, theatre, analysis, post-communism

The French philosopher and sociologist Bruno Latour opens his reflections on the present that is marked by climate change, with the following words: "The physical framework that the Moderns had taken for granted, the ground on which their history had always played out, has become unstable. As if the décor had gotten up on stage to share the drama with the actors."1 In eight lectures on the new climate regime, he introduces its characteristics and deliberates how society should react to it, and also explores the possibilities of its artistic representation. In order to outline right at the outset what his term conveys and to make it more understandable to a wider community, he reaches out to the dramatic metaphor.

Society is dominated by a stereotypical perception of theatre as a human-centred medium. The natural environment ${ }^{2}$ in drama and on stage represents mainly a backdrop for the action of a human individual or for the network of human beings. Not until long ago, nature had appeared to be the backdrop, a symbolic power and "the common good", or by its pattern of repeated phenomena (such as seasons of the year), it used to accentuate the cyclical nature of things and eternal life cycle. Much

\footnotetext{
${ }^{1}$ LATOUR, B. Facing Gaia: Eight Lectures on New Climate Regime. London : Polity Press, 2017, p. 3.

${ }^{2}$ In the entire breadth of its perception as everything that creates natural conditions for the life of organisms, (including man), but it also includes organisms (and man) per se.
} 
like society, theatre is slow in coping with new circumstances. Since the 1990s, one of the branches of literary theory, the so-called ecocriticism, has been countering the general perception of ecology in art. Its ideas are gradually transposed into theatrology and artistic practice.

Ecocriticism explores culture and various products of culture (works of art, theoretical papers, scientific theories, religious texts ...) that reflect the relationship between man and the natural environment, and it also explores how this relationship is reflected by them. It focuses on partial - theoretical, historical, pedagogical, analytical, psychological, political, philosophical - aspects of the relationship between man and the natural environment, but it also raises the issues of environmental justice. Its aim is a truly comprehensive view of the works of art through the lens of nature, the natural environment, natural sciences, ecology, environmental sciences, and other related strands. ${ }^{3}$ At present, ecocriticism no longer focuses solely on the environment and the landscape per se, but rather expands its research field to also encompass socio-ecological topics. It also seeks previously unknown authors and draws attention to the art of indigenous peoples; it finds links between environmental issues and social issues and at the same time, it applies the points of departure of a new understanding of the coexistence of man and the surrounding environment ${ }^{4}$, more precisely, of human and "more-than-human world." 5 The presented study also works with the concept of more-than-human, to make a distinction between the realm of human existence and his relations and man's relations with other living and inanimate bodies with which he/she establishes a contact, and is in a relationship with them.

With respect to performing arts, Una Chaudhuri, pioneer of ecocriticism in theatrology, contemplates a problem which does not quite apply to other art genres. In her opinion, from the time of Renaissance to say the least, theatre has been markedly anti-ecological. In one of her most frequently cited papers "There Must be a Lot of Fish in that Lake": Toward an Ecological Theater ${ }^{6}$, she alludes to a connection with the humanist tradition. In the works of the naturalists like Ibsen, Strindberg, Hauptmann and Chekhov, in which the environment used to work as a determining factor of the protagonists' characters and of the storyline, the more-than-human world continues to play the role of the co-creator of a situation, it is a building block of drama. The authors reflected on the environment through the images of vanishing cherry orchards, wild geese, and polluted spas, whereby they did not digress from the sheer portrayal of human relations. A number of contemporary playwrights base themselves on this tradition in their plays with environmental issues, abiding by the rule that drama is

\footnotetext{
${ }^{3}$ For more see BRANCH, M. - O'GRADY, S. (eds). Defining Ecocritical Theory and Practice. In Sixteen Position Papers. Salt Lake City : Western Literature Association Meeting, 1994. [online]. [cit. 1 August 2019]. Available at: http://www. asle. org/wp-content/uploads/ASLE_Primer_DefiningEcocrit. pdf.

${ }^{4}$ For more see HEISE, U. K. The Hitchhiker's Guide to Ecocriticism. In PMLA, New York : Modern Language Association of America, 2006, Vol. 121, Issue 2, pp. 503 - 514.

${ }_{5}^{5}$ The concept of the more-than-human world is described in The Spell of the Sensuous by the eco-philosopher David Abram. It is a more accurate term than the environment, as it disrupts the duality of man and the surrounding world. It includes objects that surround man, and also phenomena which man can perceive, entertain, scrutinise, experience and at the same time it includes everything that also concerns the entire natural world. Man, too, is part of the more-than-human-world.

${ }^{6}$ CHAUDHURI, U. "There Must Be a Lot of Fish in That Lake": Toward an Ecological Theater. In Theater, 1994, Vol. 25, Issue 1.
} 
a conflict between human beings. ${ }^{7}$ Using Bruno Latour's language, although the décor has gotten up on stage, it does not share the drama with the actors.

However, director and academician Downing Cless did not accept Chaudhuri's assertion, and in 2011, he wrote a key publication Ecology and Environment in European Drama. In his analyses he reveals rarely thematised, hidden, and potential starting points for playwrights when writing the works of world classics. ${ }^{8}$ Cless claims that the unique power of theatre in relation to the more-than-human world lies in the possibility of the work's interpretation. Even in the above-mentioned plays by Ibsen and Chekhov, he observes the playwrights' fondness of nature and highlights the points of departure on which they based their works. For instance, Ibsen, in his Nepriatel' l'udu [An Enemy of the People], forerunner of ecological plays, coped with a toxic crisis caused by industry and he set ecological thinking against economic thinking. Cless' approach is speculative and interpretative. He draws on an analysis of the supposed contexts of the creation of a drama text from the point of view of natural philosophy that the authors could have been knowledgeable of (for example, knowing period theories applicable to natural sciences, reading key works related to the state of the natural environment and pointing to specific concerns of their time, etc.). In Cless' understanding, the more-than-human world is gradually abandoning its role of a backdrop décor.

The theoretician Theresa J. May, like Chaudhuri, deals with the issue of the lack of relevant texts on environmental issues and considers the possibility of their presentation on stage (because theatre is not literature and everything calls for re-interpretation $^{9}$ ). She argues that an ecocritical approach in theatre should be directed toward changes in the established patterns of perception. This means encouraging a different perception of one's natural environment, bringing up the political dimensions of environmental themes, or thinking about a new future. ${ }^{10}$ The authoress also defines the term eco-dramaturgy. It is a dramaturgy that articulates the mutual being between everything that exists and its natural environment and reflects on multi-species collectives; it may lead to a new reflection on environmental history; it disintegrates established dramatic structures that continue to prioritise human conflict over more-than-human world conflicts; it advocates the topics of environmental justice, sustainability, and democracy. May's approach also lays down a clearer methodology than that of Chaudhuri or of Cless. In her article Beyond a Bambi: Toward a Dangerous Ecocriticism in Theatre Studies, she presents a simple and practical ecocritical analytical tool, a questionnaire that is applicable to various forms of cultural performance.

\footnotetext{
${ }^{7}$ MAY, T. J. Greening Theater: Taking Ecocriticism from Page to Stage. In Interdisciplinary Literary Studies, 2005, Vol. 7, Issue 1, p. 84.

${ }^{8}$ In it, he analyses Vtáky [The Birds] by Aristophanes, Doktor Faustus [Doctor Faustus] by Christopher Marlowe, Sen noci svätojánskej [Midsummer Night's Dream] by William Shakespeare, Nepriatel'a l'udu [An Enemy of the People] by Henrik Ibsen, Višňový sad [The Cherry Orchard] by Anton Pavlovich Chekhov and also the works by Brecht or Beckett.

${ }^{9}$ See MAY, T. J. Greening Theater: Taking Ecocriticism from Page to Stage, p. 85.

${ }^{10}$ See MAY, T. J. Beyond a Bambi: Towards a Dangerous Ecocriticism. In Theatre Topics, 2007, Vol. 17, Issue 2, pp. $95-110$.
} 
In a questionnaire entitled Some Green Questions to Ask a Play ${ }^{11}$, a set of questions is listed on which one may base himself/herself when perceiving the more-than-human world in drama, a production, or a performance. It allows us to seek an answer to the question whether the stage décor becomes an actor, or, how it may become an actor. The questions are as follows:

\section{Some Green Questions to Ask a Play}

1. How does a performance engage or reflect (even as "wallpaper") the environmental issues of its time and place?

2. What are the clues to the ecological conditions of the "world of the play"? How do those conditions intersect with representations of race, class, and gender?

3. How does the play reflect specific and historically situated philosophical paradigms of thinking about the human place in nature?

4. How does the play represent/complicate the effects of technology on people, animal, plants, and the land?

5. How does the play propagate or subvert the master narratives that sanction human exploitation of the land?

6. How are place and person permeable? How does the performance blur the boundaries of individual and ecological community?

7. How does the spatiality of performance inform the reciprocity among spectator, performer, and environment? How does the use of space inform notions of ecological "community"?

8. How are animal or other nonhuman bodies deployed and used as rhetorical or metaphorical devices, and what is exposed when these are re-literalized?

9. How does the body as signifier and medium function as the borderland where ecological identity is negotiated?

10. Does the performance inspire us to think newly about our relationship to the natural world and about our definitions of self or community?

11. What are the material means of production (resource/labor use) and its ecological implications (human and environmental impact)?

12. What are the material-ecological conditions of the historical moment of production, and how do these intersect with race, class, geography, and gender? ${ }^{12}$

The questionnaire is applicable to almost any dramatic work or to a work of performing arts. It goes without saying that the questionnaire would fail to meet its purpose, if it got into a confrontation with a work that completely ignores the environment, in a dramatic situation it focuses on human action and in the storyline, it only develops personal relationships between characters (i.e. purely human conflicts ensuing from individual or group behaviour). Applying it to other plays delivers more visible results that are easier to interpret. The questionnaire may facilitate the identification of the work's potential to be listed in the category of texts with environmental themes even in case of works that are not primarily connected with the theme of the human impact on the natural environment. May's questions may also provide a wider context to a creation frequently cited by ecocritics and that in the past became

\footnotetext{
${ }^{11}$ Ibid.

12 Ibid, p. 108.
} 
part of a group of dramatic texts with environmental themes ${ }^{13}$, as well as to its concrete stage forms ${ }^{14}$ or to independent performances. ${ }^{15}$

In the former Eastern Bloc countries, numerous partial studies have been developed and proceedings published aimed at deepening the understanding of the environment in the work of some authors and their impact on environmental awareness. In the Slovak context, an ecocritical approach is only being established. It is rarely used by literary theorists and historians, and it is absent from theatrology. Art historians provide comprehensive views of the events and happenings of the 1970s with a clear focus on open-air, the terrain, the natural environment, the actions of Peter Bartoš, Rudolf Sikora, Dezider Tóth, Jana Želibská. ${ }^{16}$ In 2015, a publication having international impact The Green Bloc: Neo-avant-garde Art and Ecology under Socialism by the art historian Maja Fowkes was published. In it, she captures the advent and formation of a generation of neo-avant-garde artists interested in environmental themes in socialist countries in the 1970s. It is probably the most comprehensive work on this issue, although its profiling is very narrow. It also gives a quite extensive account of the period context and it focuses on the period environmental concerns across individual countries. She writes about Czechoslovakia that "the state of the environment (...) was described as catastrophic, caused by the megalomaniacal ambitions of Communist rule to catch up to and overtake the states of the capitalist West, which were unrealistic. In the early 1970s, Czechoslovakia came to hold the first and second place in the destruction of the natural environment. The effects of pollution were so bad that it had ramifications for whole sectors of population."17

The dismal state of our environment was linked to massive industry building, collectivisation, irresponsible management of toxic waste, legal and illegal waste sites, and to a low level of environmental awareness amongst citizens. In addition, the country's leadership engaged in double talk to keep the facts on the state of the environment away from the public (it was literally a blockade). Paradoxically, it was a time when the highest number of dramatic works in the Slovak official drama literature was written with a focus on the consequences of human actions on the environment and they may be listed in the category of plays reflecting on this issue. ${ }^{18}$ However, their ecological appeal would at all times be superseded by social commitment in the name of applicable ideals. During this period, Slovak drama was a mandatory component of dramaturgic plans, and Slovak playwrights were divided mainly into those who were allowed to write and put their texts on stage and those who were "blacklisted". Once the period of the so-called socialism with a human face (late 1960s) waned, the normalisation processes in theatre resulted in a partial

${ }^{13}$ Most frequent are Búrka [The Tempest] by William Shakespeare, Nepriatel' l'udu [An Enemy of the People] by Henrik Ibsen, Ujo Váňa [Uncle Vanya] by Anton Pavlovich Chekhov, Bláznivá zo Chaillot [The Madwoman of Chaillot] by Jean Giradoux, Koniec hry [Endgame] by Samuel Beckett, Earthquakes in London by Mike Bartlett.

${ }^{14}$ For example, Pl'úca [Lungs] by Duncan Macmillan, directed by Katie Mitchell in Schaubühne Berlin.

${ }^{15}$ For example, Artificial Nature by Mette Ingvartsen.

${ }^{16}$ Refer to RUSÍNOVÁ, Z. a kol. Umenie akcie/Action Art 1965 - 1989. Bratislava : Slovenská národná galéria, 2001.

${ }^{17}$ FOWKES, M. The Green Bloc: Neo-avant-garde Art and Ecology under Socialism. Budapest - New York : Central European University Press, 2015, p. 11.

${ }^{18}$ For example, the plays by Ján Solovič Právo na omyl [Right to Error], Královná noci v Kamennom mori [The Queen of Night in the Stone Sea]. 

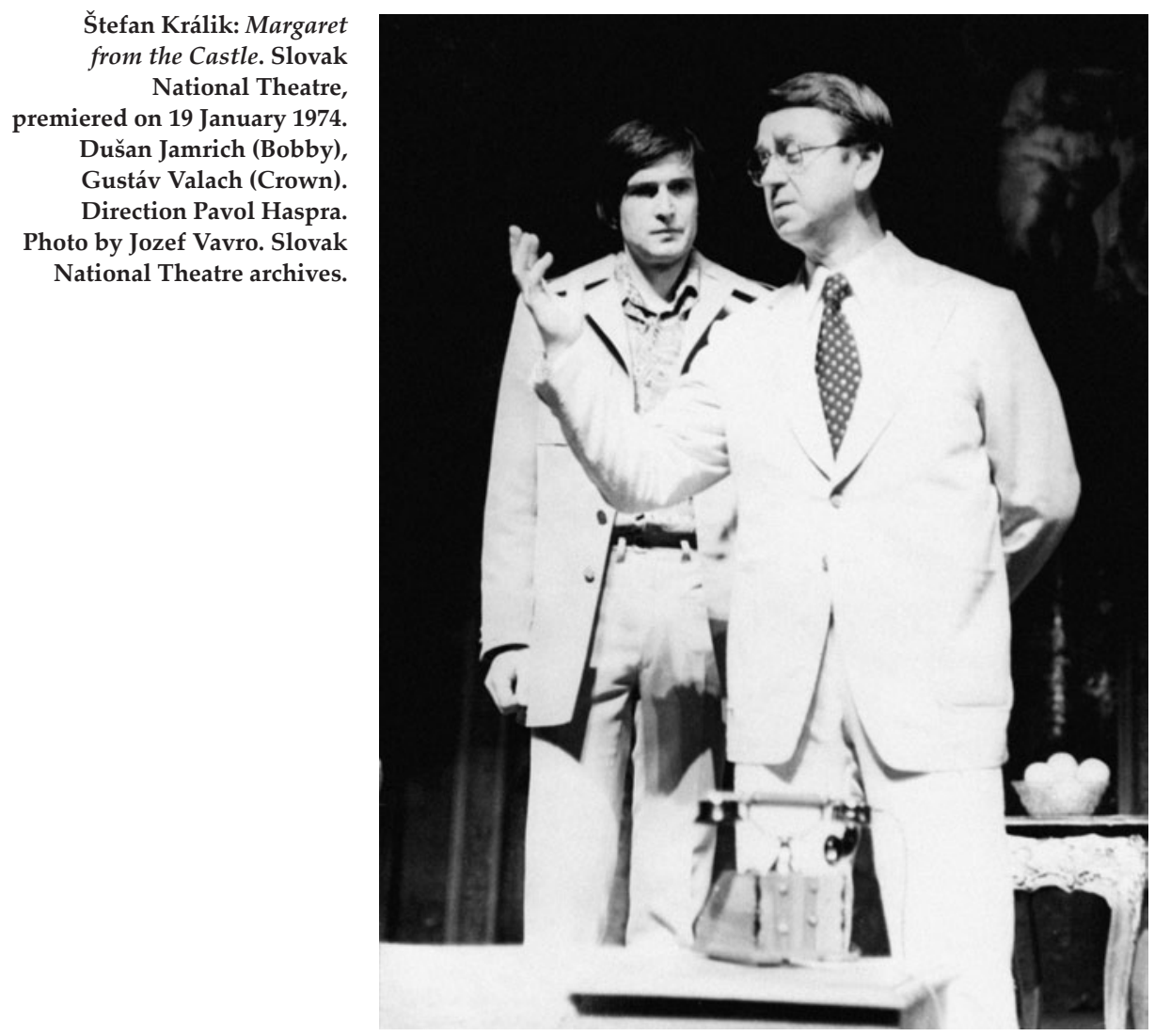

comeback of the aesthetics of socialist realism, i.e. "of the portrayal of reality and of favouring classical play composition. "19 However, the requirements to be met by authors existed especially at the ideological level. Unlike the 1950s, drama no longer had to be a devoted "handmaid of ideology" ${ }^{20}$, yet, it was at least expected not to put up stiff political resistance or to question the ideology.

Apparently this was the reason why a local environmental issue could not constitute the core of the drama Margaret zo zámku [Margaret from the Castle], written in $1974 .^{21}$ The plot from the capitalist but politically unstable Italy where social unrest peaked in the 1970s, was ideologically more tolerable and adequately anti-western oriented. In the play by Štefan Králik, the American oil tycoon Crown cleans his oil tankers on the Italian coastline and is the murderer of life in the coastal waters. The source of his capital made it difficult for the locals to access one of the very few jobs

${ }^{19}$ ŠTEFKO, V. Dráma slúžkou ideológie 1949 - 1960 [Drama - the Handmaid of Ideology 1949 - 1960]. In ŠTEFKO, V. a kol. Dejiny slovenskej drámy 20. storočia [History of Slovak Drama of the $20^{\text {th }}$ Century]. Bratislava : Divadelný ústav Bratislava, 2011, 320 p.

${ }^{20}$ Ibid.

${ }^{21}$ Margaret zo zámku [Margaret from the Castle] was premiered by the Slovak National Theatre on 19 January 1974. 
available, thus cutting them off from a major source of food for them, i.e. fishing and the fish. Margaret, the wife of Crown's son Bobby, rages passionately against her father-in-law. Margaret grew up in the local community and, therefore, co-organises demonstrations, drawing in both her husband and their child. She is trying to put an end to sea pollution, to save the locals and to take revenge for her dead father who had to sail far into the unknown waters due to lack of fish. However, her marriage to the billionaire's son is not a cold calculating scheme to get rid of Crown. Her tragedy lies mostly in her ambivalence. Margaret loves a man born to the tycoon family, which implies her affiliation with those who have power and make decisions. At the same time, she also is strongly opposed to the world they represent. Nature is not something business is mindful of.

Even though the play is about the contamination of a seashore by crude oil, the play has never been labelled as "ecological". The theme has either not been considered the main determining factor of the plot by the play's reviewers, or they focused more on its social and societal nature. For reasons above and due to lack of information, in the 1970s, the general public was inclined to understand ecology as being connected with environmental protection rather than with the deliberations over its state. In his epilogue to the book of dramatic texts Margaret zo zámku and Rebel [Margaret from the Castle and The Rebel], Zoltán Rampák characterises Margaret's revolt as the defiance of "the tyranny of her father-in-law in memory of the death of her father-fisherman who perished in the stormy high seas far away from the shore." 22 It alludes to the connection with the fundamental ideas of period requirements, i.e. with social commitment: "There are also other things piling up around this clearly socialist committed ideological core: love and tenderness, lyricism and emotionality, in contrast to a cold and sharp rational deliberation, which is naturally selfish, and caginess." ${ }^{23}$ He draws parallels between Margaret and Antigone and Joan of Arc. She reminds us of the heroines by walking shoulder to shoulder with the citizens of her hometown who revolt against Crown for depriving them of their livelihood and for "benumbing coastal waters near and far." 24

Within the context of our study, Rampák's remark, which shifts the ecological potential of the play to a metaphoric level, gains particular weight. He notes that Margaret's "attachment to the cleanliness of sea waters that wash her native town may also be understood metaphorically" 25 as a "struggle for the purity of the world and of interpersonal relations in it counter to the law of the jungle enforced by powerdriven Crown." ${ }^{26}$ Rampák highlights the contrast between Margaret who represents the people and Crown who represents big business. He brings to the surface several sub-motifs in Králik's drama, completely discounting the side of woman as a nature conservationist, of literally an ecofeminist, to use the current term. ${ }^{27}$ The sirocco wind as one of the natural elements incorporated in the play by Králik is attributed a sym-

${ }^{22}$ RAMPÁK, Z. Pokračovanie vo vývine [Continuation of Progress]. In KRÁLIK, Štefan. Margaret zo zámku. Rebel [Margaret from the Castle. The Rebel]. Bratislava : Slovenský spisovatel', 1975, 141 p.

${ }^{23}$ Ibid., p. 142.

${ }^{24}$ Ibid., p. 141.

${ }^{25}$ Ibid.

${ }^{26}$ Ibid.

${ }^{27}$ Ecofeminism is a philosophical stream which addresses the historical parallels between the oppression of women and the oppression of nature. 


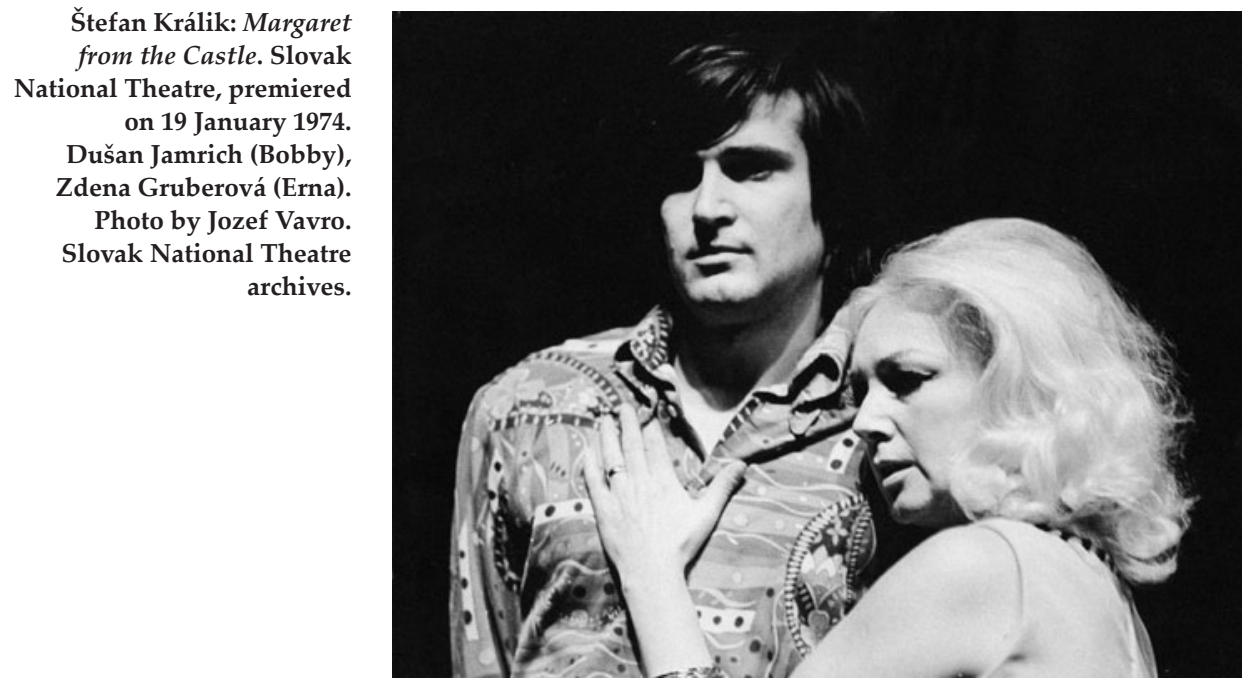

bolic value by Rampák, of a premonition "of a tragic death of the main protagonist engaged in a futile struggle with a tyrant and multi-billionaire." 28 The more-thanhuman world, the wind, is interpreted by Zoltán Rampák merely as a symbol of human conflict.

Yet, in the eyes of our contemporary the play is understood differently. Martin Timko in Dejiny slovenskej drámy 20. storočia [20 ${ }^{\text {th }}$ Century Slovak Drama] points to an inconsiderate approach of man to nature. ${ }^{29}$ However, the motif is addressed marginally, and it is social responsibility which is accentuated. In the final part of the chapter dedicated to the author, the issue of an ecological appeal in Králik's penultimate play is again brought to the fore. He makes the first step toward ecocritical analysis in stating that "... although the play was created in the mid-1970s, it is more current now than it was at the time it was written. The world of today is pestered by environmental disasters more than ever." ${ }^{30} \mathrm{He}$ adds that Crown in the lead role could be replaced by Rajendra Pachauri, former chairman of the International Panel on Climate Change. This seemingly innocent comment reveals the opinion of a sceptic ${ }^{31}$ and, at the same time, it shows that the play has the potential to be found intriguing by contemporaries. Today, a more apt comparison would be that with Donald Trump. As early as 1989, Félix Guattari in The Three Ecologies juxtaposed Trump and ecology: "In the field of social ecology, men like Donald Trump are permitted to proliferate freely,

${ }^{28}$ RAMPÁK, Z. Pokračovanie vo vývine [Continuation of Progress]. In KRÁLIK, Štefan. Margaret zo zámku. Rebel [Margaret from the Castle. The Rebel], 142 p.

${ }^{29}$ See TIMKO, M. Štefan Králik. In ŠTEFKO, V. a kol. Dejiny slovenskej drámy 20. storočia [History of Slovak Drama of the $20^{\text {th }}$ Century], 296 p.

${ }^{30}$ Ibid., 310 p.

${ }^{31}$ Rajendra Pachauri had chaired the Panel until 2015, he was co-responsible for Climategate case of 2009, which revealed possible tampering of data by climatologists, to give climate change a more dramatic image. (The charges were never confirmed by independent investigators). In addition, he was also liable for a misstatement in the Panel's annual report indicating an early melting of Himalayan glaciers. The allegations of his linkage with the business community and sexual abuse have not been proven so far. 


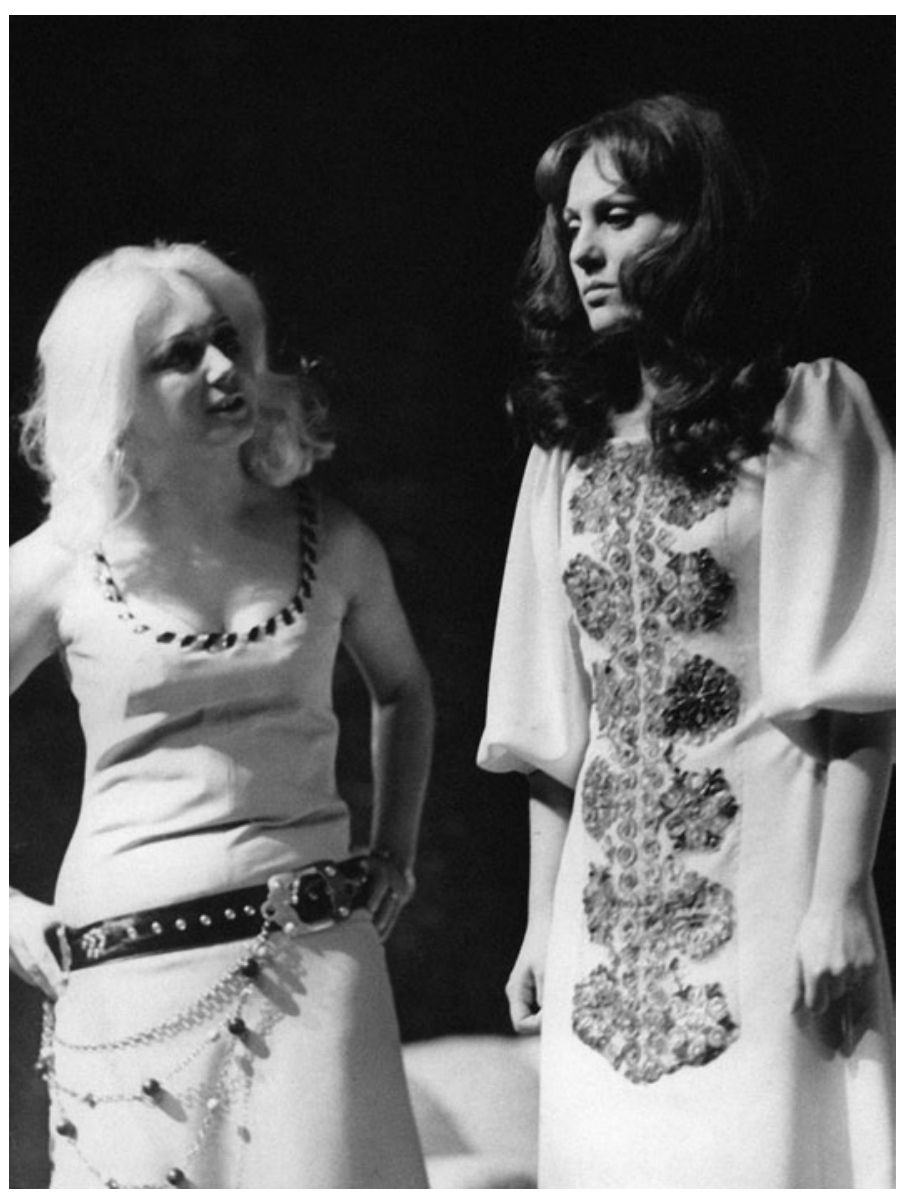

Štefan Králik: Margaret from the Castle. Slovak National Theatre, premiered on 19 January 1974. Zdena Gruberová (Erna), Soňa Valentová (Margaret). Photo by Jozef Vavro. Slovak National Theatre archives.

like another species of algae, taking over entire districts of New York and Atlantic City; he 'redevelops' by raising rents, thereby driving out tens of thousands of poor families, most of whom are condemned to homelessness, becoming the equivalent of the dead fish of environmental ecology." ${ }^{2}$ This is exactly the situation of the fishermen in Králik's play who, by being deprived of the access to the sea, are denied a source of living and lose part of their natural environment. Given the fact that the presented study contemplates the 1970s in the retrospect, the most appropriate parable when it comes to period contemplation would be that with the shipping tycoon Aristotle Onassis. Under socialism, in the then Czechoslovakia, the Greek businessman epitomised a rich capitalist, exploiter and debauchee.

${ }^{32}$ GUATTARI, F. The Three Ecologies. London : The Athlone Press, 2000, p. 43. 


\section{A Few Green Questions on the Dramatic Text of Margaret from the Castle}

Reflecting on the historical parallel between Crown and the representatives of contemporary society is an inconspicuous, yet a conscious step in the territory of May's questionnaire. How does the play Margaret from the Castle engage or reflect (even as "wallpaper") the environmental issues of its time and place? In it, an author from the Eastern Bloc countries reflected on the period issues of the West. It can be assumed that Králik's approach was partly documentary. He never specified whether he was inspired by a real situation in coastal waters, by a particular shipping tycoon, or he simply thought up the character of a Machiavellian entrepreneur. In other plays, Králik also worked with documentary reality transformed into his own poetic form (Svätá Barbara [Saint Barbara], Vojenský kabát Jura Jánošíka [The Military Coat of Juro Jánošík], Rebel [The Rebel]) - although he never worked with actual facts, he let himself be inspired by them. In his autobiography Mikromemoáre, [Micro-memoirs], he sought "poetry in a documentary" 33 and he "detested fabrication" 34 in arts.

Štefan Králik was a medical doctor by profession, so he probably also had access to information about the impacts of toxic substances on man and the environment, as well as to extensive information about global events. The 1960s were the golden age of world oil trade. Countries, big corporations, and small companies made fortune on it. ${ }^{35}$ In 1967, the first big oil spill disaster was reported. The US Torrey Canyon super tanker released about 120,000 tons of oil into the waters near Cornwall. The consequence was a devastating environmental damage causing the death of thousands of aquatic birds and innumerable fish and aquatic organisms. Until 1974, it had not been the first or last accident of this kind. For example, the first major oil spill in Nigeria in 1970 creates a historical parallel to Králik's plot because it had a devastating impact on local communities. Shell Oil Company polluted the rivers where local fishermen caught fish as well as local farmers' fields. ${ }^{36}$ Entrepreneurs like Crown controlled the oil market and their profit-oriented strategies annoyed society. In this regard, however, Králik's contemporary in Slovakia could not be affected by the play. The character of Crown was a mythical class enemy from behind the Iron Curtain. The prospective viewer/reader could perceive the play from a distance and focus on the heroine's dilemmas, her defiance of injustice. Even if the viewer/reader had a first-hand knowledge of the controversial locations in Slovakia that were associated with oil (for example, goudron landfills at Predajná, Central Slovakia, or in the Bratislava city part of Devínska Nová Ves), the blame for their existence could probably not be put on another Crown but rather on the Czechoslovak Socialist Republic which kept their existence covert.

Two of May's questions, namely "What are the clues to the ecological conditions of the 'world of the play'?" and "How do those conditions intersect with represen-

${ }^{33}$ RAMPÁK, Z. Dramatik Štefan Králik [Playwright Štefan Králik]. Bratislava : Slovenský spisovatel', 1975, p. 224.

${ }^{34}$ Ibid.

${ }^{35}$ MCKNIGHT, S. Calm before the Storm: The Global Oil Industry in the 1960s. [online]. [cit. 1 August 2019]. Available at: https://www.scmcknight. com/home/2018/11/27/calm-before-the-storm-the-global-oilindustry-in-the-1960s.

${ }^{36}$ See OSUAGWU E. S. - OLAIDA, E. Effects of oil spills on fish production in the Niger Delta. In PLOS ONE, 2018, Vol. 13, Issue 10 [online]. [cit. 1 August 2019]. Available at: https://journals. plos. org/plosone/ article?id=10.1371/journal.pone.0205114. 
tations of race, class, and gender?" combined by the theorist into one aspect of the analysis, create a relatively wide scope for deliberation. Most of the dramatic situations take place inside a luxury castle, but the dramatic space determining the conflict encompasses the castle's immediate vicinity and remote surroundings - the village, the coast, the sea. This implies that the ecological conditions in this area are set by Crown and his ships. They pollute the coastline which has consequences upon the community whose established ways of life must be changed. Margaret aptly pins it down in a dialogue with Crown.

"Crown: ... What's your father?

Margaret: I don't have a father anymore.

Crown: Did he leave you?

Margaret: He drowned. He was a fisherman. He had to sail to the high seas.

Crown: Diesel - I get it..."37

The local community is either starving, plunging for a risky catch, or the fishermen are hired as Crown's employees, shipbuilding workers, very much like Marino, husband of Margaret's sister Gina. Although he and Gina come from impoverished villagers, they see the arrival of Crown as an opportunity. Margaret cannot adapt to that for several reasons. In addition to revenge, she is also pushed by value thinking and the fact that she is - using contemporary language - an ecofeminist. She defies the established rules of power relations. At one point, her husband Bobby embodies them, when she does not keep herself at bay: "You are my wife, I have the right to command you." ${ }^{38}$ Crown, her father-in-law, even passes himself off as the Lord Almighty: "If the Lord God could form man of the dust of the ground, then John Crown can look upon those so-called living creatures as mere fools formed from the ground." ${ }^{39}$ He demonstrates his dominance over humans and nature: "The sea is a free territory. Some catch fish and some clean oil tankers." 40

Margaret's ecofeminist position stems from her advocation of the rights of the community and of nature; she attacks a man who from his status makes decisions about the world and behaves in a superior way, who puts himself before everyone and everything else and refuses to assume any responsibility and respond accordingly. Indeed, she is motivated by personal revenge which impacts her social feel: "Your oil has devastated our sea... and taken my father." 41 (...) "I wasn't that young then not to understand what was going on... Not to feel anything but loathing for all those of you who are cynical toward the tears of the miserable and the helpless." 42

A new economic situation to which the community was exposed and which is generally associated with development - from fishing (fish-catching) to ship cleaning and seafaring (services) - is perceived by the main character not only as a local environmental injustice but also as a global issue. In Králik's text the fact is only implicitly alluded to. In response to Bobby's objection that oil tankers must be cleaned

\footnotetext{
${ }^{37}$ KRÁLIK, Š. Margaret zo zámku. Rebel [Margaret from the Castle. The Rebel], p. 24.

${ }^{38}$ Ibid., p. 34.

${ }^{39}$ Ibid., p. 32.

${ }^{40}$ Ibid., p. 53.

${ }^{41}$ Ibid., p. 31.

${ }^{42}$ Ibid., p. 60.
} 

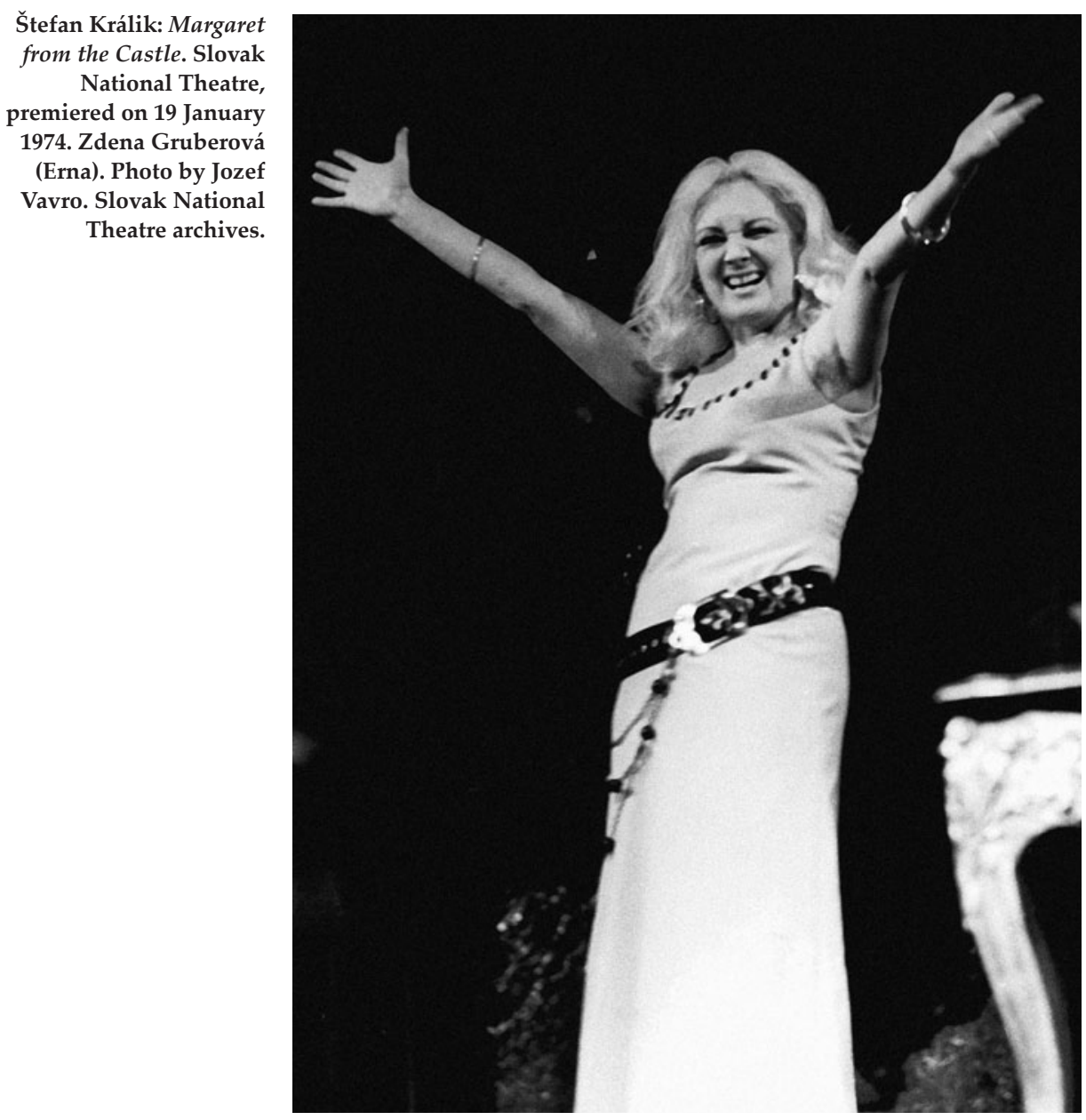

someplace, the heroine retorts: "It's got to be done someplace! Everything that until recently was worth living for must always get dirty someplace in the world." 43

Margaret understands oil business as a disproportionate action against more than the human world. The question of how the play represents/complicates the effects of technology on humans, animals, plants, and land has been partly answered, yet, it prompts further contemplations over Margaret's position. Oil rush is responsible for the devastated nature on the coastline, with fish dying, while affecting the lives of the locals. Yet the heroine shifts Crown's responsibility beyond the borders of her native village, as far as to Vietnam and to the war in its territory: "Death also travels legally on your gasoline. For example, to Hanoi..." ${ }^{44}$ Králik captured the interconnection between individual activities, the complexity of society in which everything is related

\footnotetext{
${ }^{43}$ Ibid., p. 24.

${ }^{44}$ Ibid., p. 31.
} 
and interconnected one way or the other. The cleaning of ships on the Italian coastline changes local conditions, but oil transport has also an impact on the processes taking place on the other side of the world. Is Crown co-responsible for that? In his contemplations, Králik did not think at a scale surpassing the human dimension. Margaret responds to Crown's arguments: "And it is the children somewhere in Near of Far East that will be hit the hardest." 45 She mentions children as one of the most vulnerable groups of "the miserable and the helpless" ${ }^{46}$ whose survival depends on grownups, as they have no possibility to take decisions autonomously and effectively, they have no possibility to defend themselves. Králik remains silent about the impact of war upon the natural world. However, more-than-human bodies were in a situation similar to that of children. During the war in Vietnam chemical warfare destroyed as much as 41 per cent of mangrove shrubs, the war affected eco-systems and directly or indirectly put at risk numerous species of mammals, birds, and plants. ${ }^{47}$

Apparently, Králik worked with established reasoning that man is he for whom the more-than-human world is primarily a resource. This is an outcome of a contemplation over how Margaret from the Castle propagates or subverts the master narratives that sanction human exploitation of the land. For Crown, it is a source of revenue, for the villagers, it is a source of livelihood. Margaret's understanding of the more-than-human world may be different, especially when it comes to her emotional affinity with the landscape, which is revealed in some utterances. For instance, this is patent from a characteristics given by her sister Gina: "At the time when our father was drowned... she would be found sitting on the rocks for hours, silently gazing at the sea." 48 It is further demonstrated by a starry-eyed contemplation of our heroine: "(looking in the distance) How breath-taking and harrowing it is... all those oil tankers ceaselessly gliding on the horizon." 49

The other side, a shadow of the anthropocentrism of the main heroine, may also be recognised in Margaret's words. For instance, in one of their escalating dialogues she says: "You'll be gone and my sea will be clear and clean again..." She refers to the water around the island as "my sea". She takes possession of the more-than-human world, which, indeed, exists in a certain relationship with Margaret, but equally it exists independently of her.

Another of Theresa May's questions is interrelated with the above, namely: "How are animals or other nonhuman bodies deployed and used as rhetorical or metaphorical devices, and what is exposed when these are re-literalized in a play?" In the tragedy, the motif of tropical winds reappears over and over again. As mentioned above, in his study Zoltán Rampák alludes to using a symbolic side of the natural element. He regards air stream as "a premonition of a tragic death of the lead heroine..." 50 , since sirocco wind that was due to come, had been blowing at the time of the death of Margaret's father. However, the wind may also be understood differently, outside its symbolic connotation. The more-than-human world, the sea and the wind

\footnotetext{
${ }^{45}$ Ibid.

${ }^{46}$ Ibid., p. 60.

${ }^{47}$ Refer to WESTING, A. H. The Environmental Aftermath of Warfare in Viet Nam In Natural Resources Journal, 1983, Vol. 23, Issue 2, pp. $365-389$.

${ }^{48}$ KRÁLIK, Š. Margaret zo zámku. Rebel [Margaret from the Castle. The Rebel], p. 37.

${ }^{49}$ Ibid., p. 17.

${ }^{50}$ Ibid., p. 140.
} 


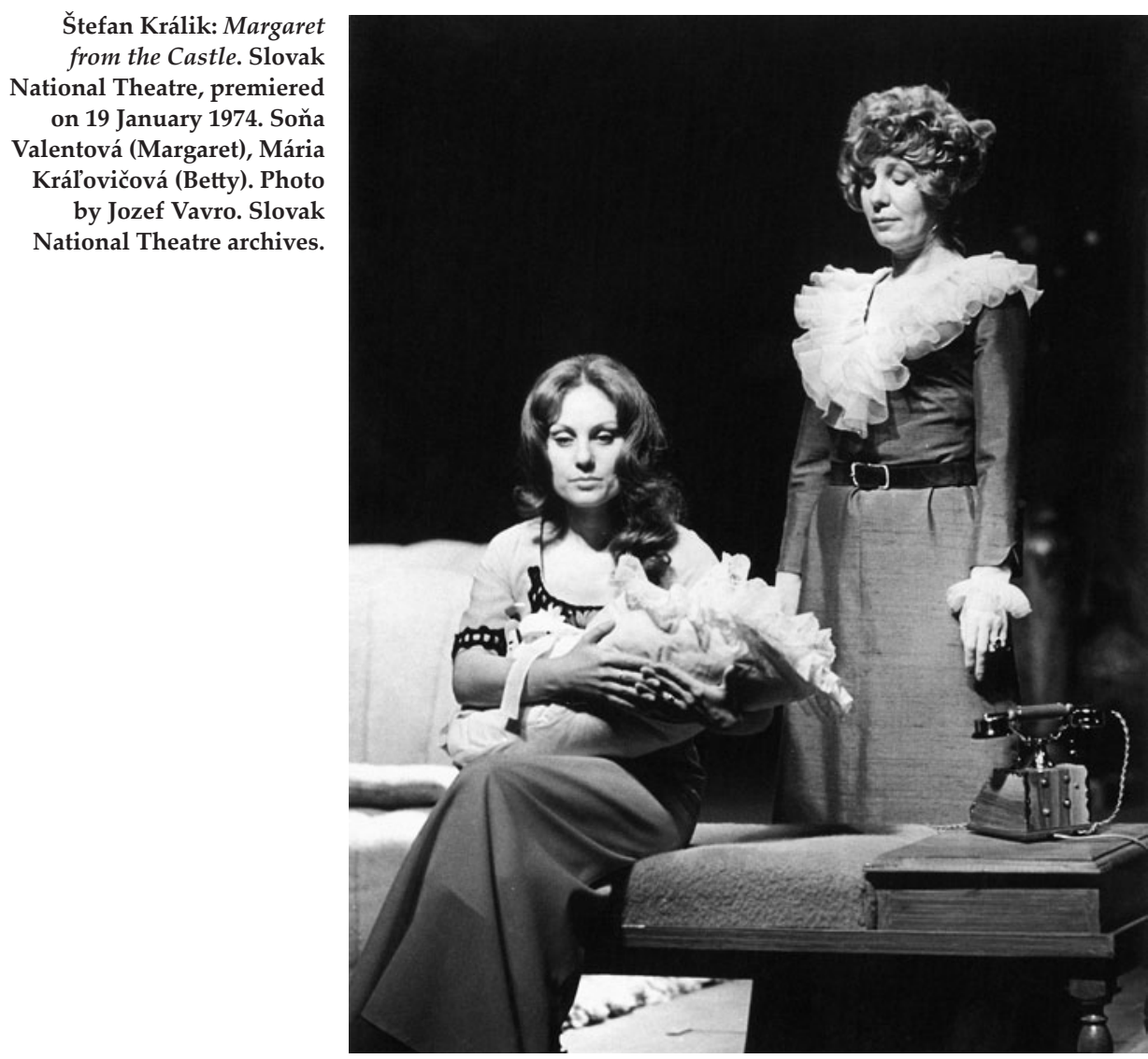

are actors of the situation right from the very first scene. The author gives them space in both the opening part and the finale, which is symptomatic in many ways. The opening playwright's stage direction characterises the situation as follows: "In the background, only blue and infinite sea and the sky... Before the stage is lit up, the sound of water gently and rhythmically lapping against the rock shore is heard." 51 Only a moment later the mistral is subdued and brought to a calm. Another change is indicated in a stage direction in the finale: "The rest will be told by sirocco, the roaring sea, and the musical motif." 52

A mere presence of the more-than-human world frames the whole human dramatic situation. But the wind and the sea keep their distance. They do not get involved in the course of events and they continue to be present outside the storyline framework. The gentle rhythm of the lapping waves turns into a hum, the mistral is subdued to a calm, only to change into the sirocco - as if they were both the observers of the conflict and actors affected, much like the locals-marchers organising a rally and assassination.

\footnotetext{
${ }^{51}$ Ibid., p. 10 .

52 Ibid., p. 63.
} 
The conflict, which ends by the death of Margaret and by the explosion of the ship with Crown, Bobby, and little Pauletto aboard, means, above all, the end of pollution. Sooner or later, the life in coastal waters will be restored. The death of all characters is tragic from a human point of view, from a more-than-human world point of view and, apparently, from the community point of view, it is a bizarre happy end. It is a return to the initial state before oil boom.

The tragedy, as observed by Zoltán Rampák in 1974, portrays "an open and immediate clash between such antagonistic forces of our time" ${ }^{\prime \prime 3}$, by which he means the struggle of the proletariat against imperialism. Margaret from the Castle condemns the conduct of an exploiter, American businessman, and capitalist who disregards the damage caused to a class of poor workers by the way he acts, and for whom Margaret stands up. Nature seems to have fallen hostage to the playwright's tactics who wanted to demonise the character of Crown, embodying one of the central enemies of socialism. This apparent author's involvement leads to a final question that could be crucial for potential Eastern Bloc ecocritics. Looking through the lens of May's questionnaire, Margaret from the Castle turned out to be one of the key Slovak contributions to eco-dramaturgy. After the application of ecocritical criteria, the play from the normalisation period that does not rank among the author's masterpieces, becomes a showcase drama piece with an environmental theme. This is a trap for the analyses drawing on ecocritical approach, as they disregard essential contextual concerns of the work's creation such as, for instance, socio-political coordinates and the purpose with which the play originally came out. Can an ecocritical interpretation of plays that have been written within the framework of ideology-based poetics automatically mean the acceptance of their original intents? And will ecological accentuation not be understood as yet another ideology (given the fact that the past was associated with the socialist committed dramaturgy)? These are the two biggest challenges facing ecocriticism not only in Slovakia but also in other former Eastern Bloc countries, which the ecocritically oriented theatrology in the West is not exposed to. Once they come to grips with them, it will indeed be the first step toward the décor effectively sharing the drama with the actors in our country.

\section{LITERATURE}

BRANCH, Michael - O'GRADY, Sean (eds). Defining Ecocritical Theory and Practice. In Sixteen Position Papers. Salt Lake City : Western Literature Association Meeting, 1994. [online]. [cit. 1 August 2019]. Available at: http://www. asle. org/wp-content/uploads/ASLE_Primer_DefiningEcocrit. pdf.

CLESS, Downing. Ecology and Environment in European Drama. New York : Routledge, 2010, 244 p. ISBN 9780415804394.

FOWKES, Maja. The Green Bloc: Neo-avant-garde Art and Ecology under Socialism. Budapest - New York : Central European University Press, 2015, 308 p. ISBN 978-615-5225-92-5.

GUATTARI, Félix. The Three Ecologies. London : The Athlone Press, 2000, 174 p. ISBN 048s 00408 9 HB.

HEISE, Ursula. K. The Hitchhiker's Guide to Ecocriticism. In PMLA, New York : Modern Language Association of America, 2006, Vol. 121, Issue 2, pp. 503 - 514. ISSN 0030-8129.

${ }^{53}$ Ibid., p. 141. 
CHAUDHURI, Una. "There Must Be a Lot of Fish in That Lake": Toward an Ecological Theatre. In Theatre, 1994, Vol. 25, Issue 1. ISSN 0161-0775.

KRÁLIK, Štefan. Margaret zo zámku. Rebel [Margaret from the Castle. The Rebel]. Bratislava : Slovenský spisovatel', 1975, 243 p.

LATOUR, Bruno. Facing Gaia: Eight Lectures on New Climate Regime. London : Polity Press, 2017, 300 p. ISBN 97-8074-568-43-45.

MAY, J. Theresa. Beyond a Bambi: Towards a Dangerous Ecocriticism. In Theatre Topics, 2007, Vol. 17, Issue 2, pp. 95 - 110. ISSN 1054-8378.

MAY, Theresa J. Greening Theatre: Taking Ecocriticism from Page to Stage. In Interdisciplinary Literary Studies, 2005, Vol. 7, Issue 1, pp. 84 - 103. ISSN 1524-8429.

MCKNIGHT, Scott. Calm before the Storm: The Global Oil Industry in the 1960s. [online]. [cit. 10 July 2019]. Available at: https://www.scmcknight. com/home/2018/11/27/calm-before-the-storm-the-global-oil-industry-in-the-1960s.

OSUAGWU Eze Simpson - OLAIDA, Eseoghene. Effects of oil spills on fish production in the Niger Delta. In PLOS ONE, 2018, Vol. 13, Issue 10. [online]. [cit. 1 August 2019]. Available at: https://journals.plos.org/plosone/article?id=10.1371/journal.pone.0205114.

RAMPÁK, Zoltán. Dramatik Štefan Králik [Playwright Štefan Králik]. Bratislava : Slovenský spisovatel', 1975, $240 \mathrm{p}$.

RUSÍNOVÁ, Zora (ed). Umenie akcie/Action Art 1965-1989. Bratislava : Slovenská Národná Galéria, 2001, 318 p. ISBN 80-8059-054-0.

ŠTEFKO, Vladimír a kol. Dejiny slovenskej drámy 20. storočia [History of Slovak Drama of the $20^{\text {th }}$ Century]. Bratislava : Divadelný ústav Bratislava, 2011, 816 p. ISBN 97-8808-936-936-2.

WESTING, Arthur, H. The Environmental Aftermath of Warfare in Viet Nam. In Natural Resources Journal, 1983, Vol. 23, Issue 2, pp. 365 - 389. ISSN 0028-0739.

Milo Juráni

Divadelná fakulta

Vysoká škola múzických umení

Zochova 1

81301 Bratislava

e-mail: jurani.miloslav@gmail.com 